\title{
Köyde Rekreasyon Engelleri Ölçeği Geçerlilik ve Güvenirlilik Çalışması
}

\author{
A Study of the Validity and Reliability of the Recreation Barriers \\ Inventory in the Village
}

\section{Nazlı Deniz ÖZ * Faik ARDAHAN **}

\begin{abstract}
Öz: Bu çalışmanın amacı; köyde yaşayan bireylerin serbest zaman engelleyicilerini belirlemek için, "Köyde Rekreasyon Engelleri Ölçeğinin- KREÖ” geçerlilik ve güvenirlilik çalışmasını yapmaktır. Örneklem Antalya kent merkezine $12 \mathrm{~km}$ uzaktaki Karatepe ve Gökçam Köyünden toplam 231 kişiden oluşmaktadır. Veriler bu çalışmanın amacına uygun geliştirilen ve iki bölümden oluşan anket formu kullanılarak "yüz yüze anket" metoduyla toplanmıştır. Çalışmada KREÖ için beşli Likert ölçeği (1- Kesinlikle Beni İfade Etmiyor, ..., 5- Kesinlikle Beni İfade Ediyor) kullanılmıștır. Anket formunun ikinci bölümünde yer alan Köyde Rekreasyon Engelleri maddelerinin geliştirilmesinde, Alexandris ve Carrol'ın (1997) geliştirdiği ve Türkçe uyarlamasını Karaküçük ve Gürbüz’ün (2006) yaptığı Boş Zaman Engelleri Ölçeği ve Öcal'ın (2012) geliştirdiği "Serbest Zaman fiziksel Aktivite Kısıtlayıcıları Ölçeği” maddelerinden faydalanılmıştır. Çalışmada KMO (0.798) ve Bartlett küresellik testlerinin $\left(X^{2}=9503.612, S D=990\right.$, $\mathrm{p}=0.000$ ) sonuçlarına göre ölçeğe açıklayıcı faktör analizi (AFA) uygulanabilir olduğu için AFA uygulanmış, modelin geçerlilik ve güvenirliliği yapılmış ve KREÖ’nin alt boyutları ortaya konulmuştur. Ölçeğin iç tutarlılığı $(0.847)$ ve açıklanan varyans oran $1 \% 78.56$ olarak bulunmuş ve sonuçlar 0.01 ve 0.05 anlamlılık düzeyinde sorgulanmıştır. Sonuç olarak ölçek toplam 11 faktörden oluşmaktadır ve sonuçlar KREÖ'nün Türk popülasyonu için geçerli ve güvenilir olduğunu göstermektedir.
\end{abstract}

Anahtar sözcükler: Köy, Köy ve Rekreasyon, Rekreasyon, Köyde Rekreasyon Engelleri

Abstract: The aim of this study is to developed and define the validity and reliability of "Recreation Constraints Inventory in the Village (RCIV)". The sample group consists total 231 people (72 females and 58 males from the Karatepe village and 48 females and 53 males from the Gökçam village) subjecting to the district $12 \mathrm{~km}$ away from Antalya. In this study, for data collection, the designed two sectioned questionnaire form derived from Leisure Time Consists Inventory, developed by Alexandris and Carrol (1997) and adapted in to Turkish by Karaküçük and Gürbüz (2006) and Leisure Time Physical Activity Restrictors Inventory developed by Öcal (2012) used. Face to face method performed for data collection. The RCIV were 5-point Likert scale (1- It does not definitely refer to me, ..., 5- It definitely refers to me ).According to the results of KMO (0.798) and Bartlett's Test of Sphericity $\left(\mathrm{X}^{2}=9503.612\right.$, $\mathrm{SD}=990, \mathrm{p}=0.000$ ), Explanatory Factor Analysis (EFA) was applicable to the inventory. For validity and reliability, AFA was run and sub dimension of RCIV obtained. The internal consistency as 0.847 and cumulative variance as $78.567 \%$ were found. The results have been assessed in 0.01 and 0.05 significant level. As a result, the constraints participating recreational activities grouped in to 11 factors These findings show that RCIV has validity and reliability for the Turkish population

Keywords: Village, Village and Recreation, Recreation, Recreation Barriers in Village

\footnotetext{
* Arş. Gör., Selçuk Üniversitesi, Spor Bilimleri Fakültesi, Rekreasyon Bölümü, Konya. denizyilmaz@selcuk.edu.tr https://orcid.org/0000-0001-9187-8596

** Doç. Dr., Akdeniz Üniversitesi, Spor Bilimleri Fakültesi, Rekreasyon Bölümü, Antalya. ardahan@akdeniz.edu.tr https://orcid.org/0000-0002-5319-2734
} 
Giriş

Köy; “Genelde tarımla uğraşan, içinde bulundukları toplumun bütünüyle ortak çıkarları az olan, sinırlı ölçüde örgütlenmiş bulunan, birbirleri karşısında da güçlü özerklik eğilimleri gösteren; toplumsal çevreden çok doğal çevreyle yoğun ilişkilerde bulunan, birkaç düzine ile birkaç yüz arasinda hanelerden kurulu, belli ve özenle korunan sinırları bulunan topluluklardır" (Ozankaya 1987, 32-40). Toplumsal hayatta birçok neden ve kaynağa bağlı sorunlarla karşılaş1rız, sorunlar çözülmeden bir yenisi karşımıza çıkabilir. Köyden kente göç, gecekondulaşmanın artışı, kentlileşememe, kentteki işsizlik düzeyinin artışı, muhtemel radikalleşme riski, suç düzeyindeki artış, sosyal ve psikolojik sorunlar ve vakalarda gözlemlenen artış gibi birçok toplumsal problemin temelinde, "insanları doğduğu yerde doyuramama ve insanca yaşatamama" gerçeği saklıdır. 1993 yılı itibariyle ilçe merkezi sayısı 836 iken 2017'de 919'dur. Yine 1993 yılı değerlerine göre Türkiye'de 35.544 köy mevcutken 2017 'de bu sayı 18.329'dur. Bu azalmanın nedeni köyden kente göçtür. Öte yandan ülkemizde bu idari sistem dışında kalan bir takım köyden küçük yerleşmeler ise mezra, kom, yayla, bağ evidir, bir başka ifadeyle köy-altı yerleşmeleri de vardır ki bunların sayısı tahminen 50.000'den fazladır. Köy-altı yerleşme birimleri içinde sayı itibariyle yaylalar (26.000 civarında) ve komlar (9800 civarında) başta gelir (Gümüş 2016, 9092). Gelişmiş toplumların rekreasyon aktivitelerine ihtiyaç duymasındaki temel sebepler bireysel özgüveni ve toplumsal beraberliği sağlamadaki etkileridir.

İnsanoğlu varoluşunun her döneminde zaman ile yarış halindedir. Kendisini idame için yapılacak işleri ve kendilerine ayırmaları gereken vakitlerin farkındalığında zaman yönetimini öğrenmişlerdir. Zamanı iyi kullanmak beraberinde kaliteli bir yaşam için gerekli olan disiplini getirir. Bu disiplin ile beraber bireylerin ihtiyaç duyduğu, planlı veya plansız uygulayabilecekleri etkinlik ve gerekliliklere verimli bir şekilde vakit ayırabilme ve hobi edinebilme imkânları tanır. Böylece kişi zorunlulukları ve kişisel yaşamı arasında denge kurabilme yetisi kazanabilir.

Ardahan ve arkadaşları (2016) rekreasyonu izleyen şekilde tanımlamıştır: "Insanların serbest zamanlarında özgür iradeleri ile yalnız veya grupla zevk alarak yapabildikleri ve bunun sonucunda eğlendikleri, dinlendikleri, bedenen ve ruhen bir tazelenme, yenilenme hissettikleri ve haz elde ettikleri etkinlikler toplamı olarak tanımlanabilir".

Rekreasyon felsefi açıdan, her yaş grubundan bireyin yaşam kalitesini arttırmak, çocukluk çağından itibaren; sağlık ve sosyal olarak serbest zamanını doğru değerlendirmek ve doğru değerleri benimsemek ve geliştirmeyi hedefler. Ayrıca, sigara, alkol ve zararlı olduğu bilinen her türlü kötü alışkanlıktan korunma veya arınma, daima aktif ve efektif yaşam tarzını hedef alan, aile ve toplum ile sosyal bakımdan uyum içinde olma gibi olgular da kazandırılması amaçlanır. Aile sorumluluğunda iken bu alışkanlıklar, okul çağında pekişir. Bu nedenle sağlıklı yaşam ve egzersiz konusunda, bireylerin, ailelerin, eğitimcilerin, toplum liderlerinin ve yöneticilerin bilinçli olması önem arz etmektedir (Zorba et al. 2013).

Geçmişten günümüze, evrensel bir ihtiyaç olarak görülen ve kabul edilen serbest zaman aktivitelerinin birey, toplum ve demografik özelliklere göre değişiklik göstermesi muhtemeldir. Rekreasyon aktivitelerinin birleştirici ve bütünleştirici etkisi göz önüne alındığında özellikle çağımızda büyüyen din, dil, ırk, cinsiyet, kültür vb. gibi farklılıkların bireyler arası veya toplumlararası "öteki” algısını yıkmakta ve "farklılığa hoşgörü" faydasını sağlamaktadır (Ardahan 2013).

\section{Rekreasyona Katılımın Önündeki Engeller}

Rekreasyon bilimi günümüzün stres altındaki bireyleri için bir güdüleme faktörü olma özelliği ile gittikçe önem kazanmaktadır (Özışık 1988). Yapılan birçok araştırmaya istinaden söyleyebiliriz ki, rekreatif faaliyetler hem toplumsal hem de bireysel sağlığı olumlu etkiler. Rekreatif faaliyetlerin pozitif yönlü etkilerine rağmen kişilerin çeşitli sebepler ile kendileri için oldukça yararlı olan bu tür faaliyetlere katılmamayı tercih ettikleri ya da çeşitli engellerin katılımlarını 
engellediğini söyleyebiliriz (Karaküçük \& Gürbüz 2006). Yapılan ampirik çalışmaların sonuçlarına göre ise, bireyin rekreasyonel aktivitelere katılımını etkileyen temel faktörler önem sırasına göre; "para”, "zaman”, "arkadaş eksikliği”, "ulaşım” ve "tesis" olarak belirlenmiştir (Shinew et al. 2004; Koçak 2005). Alexandris ve Carroll'un (1997) bilimsel çalışmasında cinsiyetin rekreasyonel etkinlikte bulunmada olumlu bir etkisi olduğunu belirtilmiştir. Balcı'da (2003) yapmış olduğu araştırmada, gelişmiş ülkelerde serbest zamanların değerlendirilmesinde çeşitli kültürel ve mesleki faaliyetlerin ön planda olduğu, az gelişmiş ve gelişmekte olan ülkelerde ise serbest zaman değerlendirilmesinde spor faaliyetlerinin ilk sırada yer aldığını belirtmiştir.

Köydeki rekreasyonel hayat yukarıda sıralanan engellerin yanında sadece köye ve hatta şehir hayatına tam entegre olamamış yaşamların içinde olan diğer bireyleri de etkileyecek başka engellerden de söz edilebilir. Bunlar aynı zamanda köy yaşamındaki sosyal ve rekreasyonel hayatı da düzenleyen, etkileyen unsurlardır. Bunların başında örf, adet, gelenek, dini inanç, toplumsal yapı, töre gibi unsurların oluşturduğu başkalarının ve ailenin baskısı gelmektedir. Bunun yanında bireylerin rekreasyonel konularda bilgi ve bilinç eksikliğine sahip olması, köyde bireylerin rekreasyonel taleplerine uygun tesislerin ve hizmetlerin olmamas1, olan hizmet ve tesislere de ulaşım sorununun olması eklenebilir. Bunların dışında, köyde hayat çok farklı unsurların bileşkesi olarak sürdürülür. Bağ, bahçe ve tarla işleri, var ise büyük ve küçükbaş hayvancılık işleri, aile bireylerinin ve evin yemek, bulaşık, temizlik, okul, ödevler, büyük ebeveynlerin bakımı gibi gündelik işler bireylerin çok fazla zamanlarını almaktadır. Bireyler bu yoğun tempoda rekreasyon bilinçleri, hatta rekreasyonel istekleri belirgin olsa bile yeteri kadar zaman yaratamayabilirler. Şehirde bireyleri rekreasyonel aktivitelere yönelten motive edici unsurların başında arkadaş etkileşimi, medyanın etkisi gibi unsurlar olsa da bunların köy yaşamında eksikliği de vardır. Köy yaşamında bireyler bu bağlamda rekreasyonel etkinliklere ilgisiz kalabilirler.

$\mathrm{Bu}$ öngörüler üzerinden değerlendirildiğinde köyde yaşayan bireylerin rekreatif etkinliğe katılımının önündeki engelleri sorgulamak için bir çalışma yapılması gerekliliği ortaya çıkmıştır. Ancak alan yazın incelendiğinde, Tablo-1'de de görülebileceği gibi, engel ölçeklerinin genellikle fiziki ve sosyal açıdan rekreatif etkinliğe ulaşma imkânı olan örneklem grupları ile geliştirildiği veya uyarlandığı görülmüştür. Dolayısı ile köyde yaşayan bireylerin sosyal, fiziki, maddi vb. birçok farklılık gösterecek engel temalarına uygun ölçek geliştirme ihtiyacı doğmuştur.

Tablo 1. Ülkemizde Kullanılan Rekreasyon Engelleri Ölçekleri

\begin{tabular}{|c|c|c|c|c|c|}
\hline Ölçek adı & Yazarlar & Y1lı & $\begin{array}{l}\text { Alt boyut ve } \\
\text { madde sayıs } 1\end{array}$ & Örneklem & Alt Boyutlar \\
\hline $\begin{array}{l}\text { Boş Zaman } \\
\text { Engelleri } \\
\text { Ölçeği }\end{array}$ & $\begin{array}{l}\text { Suat Karaküçük } \\
\text { Bülent Gürbüz }\end{array}$ & 2006 & $\begin{array}{l}6 \text { Alt boyut } \\
27 \text { Madde }\end{array}$ & $\begin{array}{l}\text { Üniversite } \\
\text { Öğrencisi }\end{array}$ & $\begin{array}{l}\text { - } \text { Birey Psikolojisi } \\
\text { - Zaman } \\
\text { - İlgi Eksikliği } \\
\text { - } \text { Sosyal Ortam ve Bilgi } \\
\text { Eksikliği } \\
\text { - } \text { Tesis, hizmet ve ulaşım } \\
\text { - } \text { Arkadaş Eksikliği }\end{array}$ \\
\hline $\begin{array}{l}\text { Boş Zaman } \\
\text { Engelleri } \\
\text { Ölçeği-28 }\end{array}$ & $\begin{array}{l}\text { Suat Karaküçük } \\
\text { Bülent Gürbüz }\end{array}$ & 2006 & $\begin{array}{l}8 \text { alt boyt } \\
28 \text { Madde }\end{array}$ & $\begin{array}{l}\text { Öğretim } \\
\text { Elemanları }\end{array}$ & $\begin{array}{l}\text { - Zaman } \\
\text { - Sosyal çevre } \\
\text { - Para } \\
\text { - Bilgi eksikliği } \\
\text { - Arkadaş eksikliği } \\
\text { - Kentsel koşullar } \\
\text { - Ulaşım } \\
\text { - Tesis }\end{array}$ \\
\hline
\end{tabular}




\begin{tabular}{|c|c|c|c|c|c|}
\hline $\begin{array}{l}\text { Serbest } \\
\text { Zaman } \\
\text { Fiziksel } \\
\text { Aktivite } \\
\text { Kisitlayıcılar } \\
\text { 1 (SZFA-K) }\end{array}$ & Kubilay ÖCAL & 2012 & $\begin{array}{l}8 \text { Alt boyut } \\
38 \text { Madde }\end{array}$ & $\begin{array}{l}\text { Üniversite } \\
\text { çalışanı } \\
\text { akademik ve } \\
\text { idari personel }\end{array}$ & $\begin{array}{l}\text { - Fiziksel Alg1 } \\
\text { - Tesis } \\
\text { - Gelir } \\
\text { - Aile } \\
\text { - Yetenek Algisı } \\
\text { - Zaman } \\
\text { - İrade } \\
\text { - Sosyal Çevre }\end{array}$ \\
\hline
\end{tabular}

\section{Yöntem}

Araştırma tanımlayıcı bir araştırmadır ve bu çalışmaya Antalya şehir merkezine $12 \mathrm{~km}$ mesafedeki Karatepe ve Gökçam Köyleriyle sınırlıdır. Ana kütle Gökçam ve Karatepe köylerindeki tüm bireylerden oluşmaktadır. Gökçam ve Karatepe köyleri tesadüfen seçilmemiştir. İki köy birbirine sınırdır ve her ikisi de Antalya'ya eşit mesafededir. Coğrafik özellikleri itibariyle aynıdır. Her iki köye de aynı toplu taşım aracı ile gidilmektedir. Her iki köyden araştırmaya dahil olmak istemiş 18 yaşın üstündeki kadın ve erkekler örnekleme dahil edilmiştir. Karatepe köyünden 130 kişi (72 kadın 58 erkek), Gökçam'dan 101 kişi (48 kadın, 53 erkek) toplam 231 kişi anket çalışmasına dâhil olmuştur.

Veri toplama aracı olarak bu çalışmanın amacına uygun olarak geliştirilen ve iki bölümden oluşan anket formu yüz yüze anket metoduyla katılımcilara verilmiş ve gerekli bilgilendirme yapıldıktan sonra geri toplanmıştır. Anketler toplandığında doldurma hataları uygulama esnasında düzeltildiği için toplanan tüm anketler değerlendirmeye alınmıştır. Anket formunun birinci bölümünde bireylere ait demografik bilgiler, ikinci bölümde köydeki rekreasyon engellerini sorgulamak için geliştirilen maddeler yer almıştır. Çalışmada KREÖ için beşli Likert ölçeği (1- Kesinlikle Beni İfade Etmiyor, 2- Beni İfade Etmiyor, 3- Kısmen Beni İfade Ediyor, 4- Beni İfade Ediyor, 5Kesinlikle Beni İfade Ediyor) kullanılmıştır. Anket formunun ikinci bölümünde yer alan Köydeki Rekreasyon Engelleri maddelerinin geliştirilmesinde, Alexandris ve Carrol'in (1997) geliştirdiği ve Türkçe uyarlamasını Karaküçük ve Gürbüz'ün (2006) yaptığı Boş Zaman Engelleri Ölçeği, Gürbüz ve Karaküçük (2007) tarafindan geliştirilen Boş Zaman Engelleri Ölçeği-28 ve Öcal'ın (2012) geliştirdiği Serbest Zaman fiziksel Aktivite Kısıtlayıcıları Ölçeği maddelerinden faydalanılmıştır. Üç çalışma da çalışmanın amacına ve örneklem grubuna uygun olmadığı için üç çalışmada yer alan maddelere ilave olarak başka maddeler de eklenerek 47 maddeden oluşan yeni bir madde havuzu oluşturulmuştur. İki madde Faktör Analizi yapıldığında düşük varyans değerleri verdiği için analizden çıkarılmış ve faktör analizi toplam 45 madde üzerinden yapılmıştır.

\section{Bulgular}

Köyde Rekreasyon Engelleri Ölçeğini-KREÖ geliştirilmek, Karatepe ve Gökçam köyleri örnekleminde Türk popülasyonu için geçerlilik ve güvenirliliğini yapmaktır.

KREÖ geliştirmek için 47 madde ile AFA uygulanmış ve elde edilen sonuçlar Tablo-2'de verilmiştir. Tablodan da görülebileceği KREÖ ölçeğinin Kaiser-Meyer-Oklin değeri Kaiser'in (1974) öngördüğü biçimde (0.60) değerinin üstünde ve Bartlett küresellik testi sonucu $P<0.05$ olarak bulunmuştur. Bu sonuçlara göre iki madde 0.50 'nin altında varyansa sahip olduğu için faktör analizinden çıkarılıp geri kalan 45 madde ile AFA yeniden yapılmış ve Bartlett küresellik testi sonucunda Ki-kare=9503.612, $P=0.000$ bulunmuş ve Keiser-Meyer-Olkin örneklem yeterlilik ölçümü 0.798 olarak hesaplanmıştır.

\begin{tabular}{|l|c|}
\hline Kaiser-Mayer-Olkin Örneklem Yeterlilik Ölçümü & 0.798 \\
\hline Yaklaşık Ki-kare & 9503.612 \\
\hline Bartlett KüresellikTesti Serbestlik derecesi & 990 \\
\hline Anlamlılık & 0.000 \\
\hline
\end{tabular}


Modelde Varimax döndürme yöntemi kullanılmıştır. Buna göre Çizim 1'de de görülebileceği gibi, tüm maddeler öz değerleri 1'den büyük olan 11 faktörde toplanmış ve toplam varyansın \%78.57'sini açıklamıştır. Ölçeğin Cronbach's Alpha değeri ise 0.847 olarak bulunmuştur.

Çizim-1 Faktör Analizi Scree Plot Sonucu

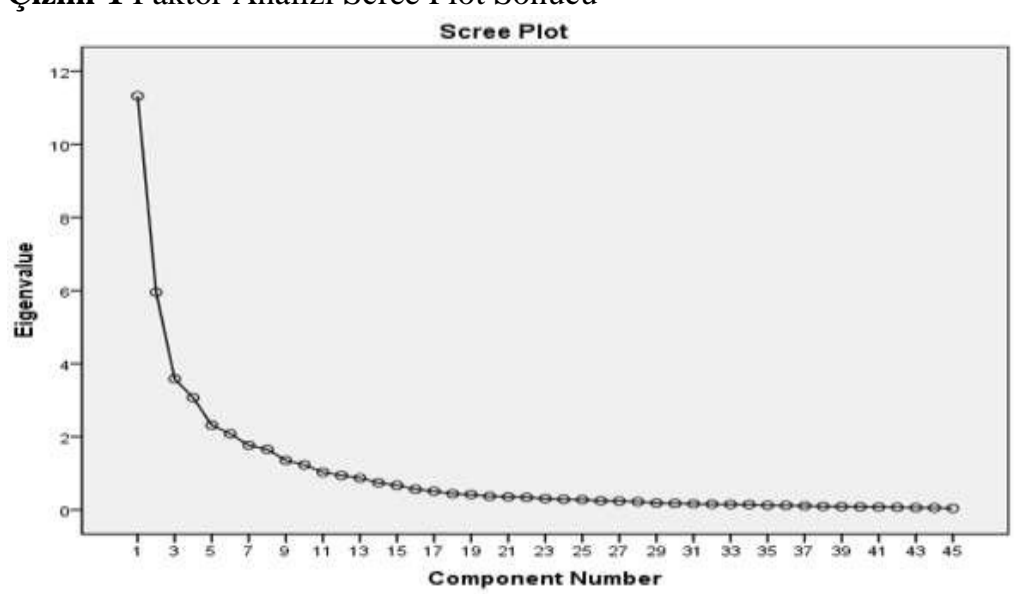

Tablo 2. Faktör Yükleri, Ortak Varyans Değerleri

\begin{tabular}{|c|c|c|c|c|c|c|c|c|c|c|c|c|c|}
\hline \multirow{2}{*}{$\begin{array}{c}\text { Madde } \\
\text { Numaraları }\end{array}$} & \multicolumn{11}{|c|}{ Faktör Yükleri } & \multirow{2}{*}{ Varyans } & \multirow[t]{2}{*}{$\mathrm{X} \pm \mathrm{SS}$} \\
\hline & F1 & $\mathbf{F} 2$ & F3 & F4 & F5 & F6 & F7 & F8 & F9 & F10 & F11 & & \\
\hline Fizik1 & 0.651 & & & & & & & & & & & 0.682 & $1.88 \pm 1.139$ \\
\hline Fizik2 & 0.815 & & & & & & & & & & & 0.837 & $1.97 \pm 1.145$ \\
\hline Fizik3 & 0.857 & & & & & & & & & & & 0.860 & $1.86 \pm 1.116$ \\
\hline Fizik4 & 0.798 & & & & & & & & & & & 0.774 & $1.90 \pm 1.171$ \\
\hline Fizik5 & 0.852 & & & & & & & & & & & 0.865 & $1.88 \pm 1.107$ \\
\hline Fizik6 & 0.796 & & & & & & & & & & & 0.778 & $2.11 \pm 1.286$ \\
\hline Fizik7 & 0.845 & & & & & & & & & & & 0.791 & $2.13 \pm 1.308$ \\
\hline Tesis1 & & 0.769 & & & & & & & & & & 0.696 & $3.64 \pm 1.385$ \\
\hline Tesis2 & & 0.805 & & & & & & & & & & 0.730 & $3.56 \pm 1.384$ \\
\hline Tesis3 & & 0.900 & & & & & & & & & & 0.859 & $3.29 \pm 1.468$ \\
\hline Tesis4 & & 0.752 & & & & & & & & & & 0.788 & $2.86 \pm 1.472$ \\
\hline Tesis5 & & 0.760 & & & & & & & & & & 0.778 & $3.18 \pm 1.503$ \\
\hline Tesis6 & & 0.770 & & & & & & & & & & 0.762 & $3.72 \pm 1.387$ \\
\hline Tesis7 & & 0.839 & & & & & & & & & & 0.796 & $3.51 \pm 1.509$ \\
\hline Baş/aile1 & & & 0.720 & & & & & & & & & 0.704 & $3.90 \pm 1.192$ \\
\hline Baş/aile2 & & & 0.831 & & & & & & & & & 0.781 & $4.10 \pm 1.081$ \\
\hline Baş/aile3 & & & 0.754 & & & & & & & & & 0.754 & $3.90 \pm 1.198$ \\
\hline Baş/aile4 & & & 0.729 & & & & & & & & & 0.783 & $4.05 \pm 1.082$ \\
\hline Baş/aile5 & & & 0.757 & & & & & & & & & 0.757 & $4.00 \pm 1.053$ \\
\hline Yetenek1 & & & & 0.820 & & & & & & & & 0.785 & $2.23 \pm 1.316$ \\
\hline Yetenek2 & & & & 0.786 & & & & & & & & 0.819 & $2.33 \pm 1.200$ \\
\hline Yetenek3 & & & & 0.442 & & & & & & & & 0.735 & $2.31 \pm 1.254$ \\
\hline Yetenek4 & & & & 0.767 & & & & & & & & 0.816 & $2.26 \pm 1.214$ \\
\hline Yetenek5 & & & & 0.719 & & & & & & & & 0.791 & $2.18 \pm 1.215$ \\
\hline Pahalı1 & & & & & 0.891 & & & & & & & 0.911 & $2.52 \pm 1.308$ \\
\hline Pahalı2 & & & & & 0.819 & & & & & & & 0.856 & $2.56 \pm 1.249$ \\
\hline Pahalı3 & & & & & 0.869 & & & & & & & 0.880 & $2.57 \pm 1.259$ \\
\hline Psiko1 & & & & & & 0.836 & & & & & & 0.851 & $2.32 \pm 1.336$ \\
\hline Psiko2 & & & & & & 0.825 & & & & & & 0.867 & $2.39 \pm 1.330$ \\
\hline Psiko3 & & & & & & 0.713 & & & & & & 0.677 & $2.35 \pm 1.307$ \\
\hline Psiko4 & & & & & & 0.485 & & & & & & 0.766 & $3.44 \pm 1.365$ \\
\hline İlgi1 & & & & & & & 0.846 & & & & & 0.817 & $2.45 \pm 1.373$ \\
\hline
\end{tabular}




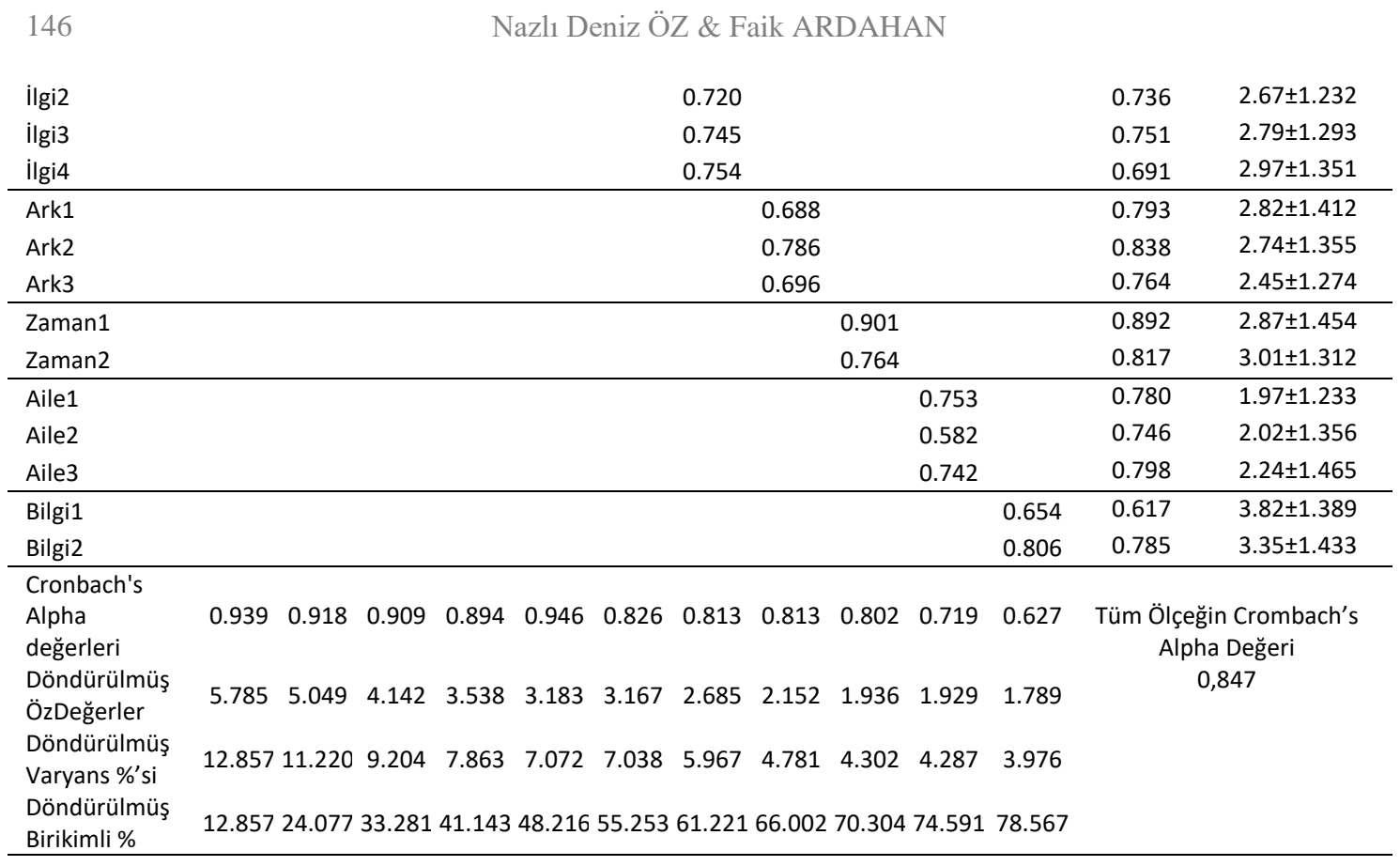

Tablo-3 'de faktörler ve maddeler arasındaki korelasyon değerleri verilmiştir. Buna göre faktörleşme ilişkileri doğru gerçekleşmiştir. Her grupta o maddenin korelasyon değerleri faktörleştiği grupta en yüksektir. KREÖ'nin toplam Cronbach's alpha değeri 0.847 'dir. KREÖ'de bulunan maddeler Tablo-4'te verilmiştir. Elde edilen faktörler, faktörlerde yer alan maddeler, Cronbach's alpha değeri ve döndürülmüş öz değerler (DD); ve Faktör-1 (F1) için DD=5.785 ve Cronbach’s alpha değeri $=0.939$, Faktör-2 (F2) için $\mathrm{DD}=5.049$ ve Cronbach's alpha değeri $=0.918$, Faktör-3 (F3) için $\mathrm{DD}=4.142$ ve Cronbach's alpha değeri $=0.909$, Faktör-4 (F4) için $\mathrm{DD}=3.538$ ve Cronbach's alpha değeri $=0.894$, Faktör-5 (F5) için $\mathrm{DD}=3.183$ ve Cronbach's alpha değeri $=0.946$, Faktör-6 (F6) için $\mathrm{DD}=3.167$ ve Cronbach's alpha değeri $=0.826$, Faktör-7 (F7) için $\mathrm{DD}=2.685$ ve Cronbach's alpha değeri $=0.813$, Faktör- 8 (F8) için $\mathrm{DD}=2.152$ ve Cronbach's alpha değeri $=0.813$, Faktör-9 (F9) için DD=1.936 ve Cronbach's alpha değeri=0.802, Faktör-10 (F10) için DD=1.929 ve Cronbach's alpha değeri $=0.719$ ve Faktör-11 (F11) için $\mathrm{DD}=1.789$ ve Cronbach's alpha değeri $=0.627$ olarak bulunmuştur. AFA ile elde edilen faktörler aşağıdaki gibi isimlendirilmişlerdir: F1: "İlgisizlik" adı verilen bu faktör bireylerin "Geçmişte bu tür etkinlikleri sevmemek", "Bu tür etkinliklere ilgili olmamak", "Gündelik hayatın akışını bozmak istememek" ve "Bu tür aktivitelere başlamayı sürekli ertelemeyi" maddelerini tarifleyen unsurlardan oluşur.

F2: "Tesis-Hizmet-Ulaşım" adı verilen bu faktör bireylerin "Yakın civarımda katılabileceğim aktivitelerin olmaması", "Aktivitelerin yapılması için tesislerin olmaması", "Aktivitelerin yapılması için tesislerin yetersiz olması", "Aktivitelerin yapılabileceği tesislerin kalabalık olması", "Aktivitelerin yapılabileceği tesislerin kalabalık olması", "Bana uygun aktivite olmaması", "Aktivitelerin yapıldığı yere ulaşımın zaman alması" ve "Aktivitelerin yapıldı̆̆ yere ulaşımın olmamasini" tarifleyen unsurlardan oluşur.

F3: "Yetenek Algısı" adı verilen bu faktör bireylerin "Bu aktiviteleri sürdürebilecek iradeye sahip değilim”, "Bu aktivitelerden çabuk sılklacă̆ımı düşünüyorum”, "Bu aktiviteleri hayatıma katmaya hazır değilim”, "Bu aktiviteleri yapacak kadar yetenekli olduğumu düşünmüyorum” ve "Bu aktivitelerin gerektirdiği özellikler kişisel becerilerimle uyuşmuyor" maddelerini tarifleyen unsurlardan oluşur.

F4: "Başkaları ve Ailenin Baskısı" adı verilen bu faktör bireylerin "Komşularımdan çekiniyorum/utanıyorum", "Bu aktivitelere katılmam ailemi çevreye karşı zor durumda birakabilir", "Bu aktivitelere katılmam ailem tarafindan hoş karşılanmıyor", "Ailem bu aktivitelere katıl- 
mama izin vermiyor" ve "Aile bireylerinden çekiniyorum/utanıyorum" maddelerini tarifleyen unsurlardan oluşur.

F5: "Birey Psikolojisi" adı verilen bu faktör bireylerin "Bu aktiviteleri yaşıma uygun bulmuyorum", "Bu aktiviteleri benim yaşımdakiler yapmazlar", "Başkalarının katıldĭ̆ı ortamlardan mutlu olmamak" ve "Boş zamanlarımı ailem için ayırmak zorunda olmayı" tarifleyen unsurlardan oluşur.

F6: "Zaman Yetersizliğ i" adı verilen bu faktör bireylerin "İ̧̧/çalışma zamanının yoğun olması" ve "Aile/Iss sorumluluklarım nedeniyle aktivitelere zaman aylramıyorum" maddelerini tarifleyen unsurlardan oluşur.

F7: "Bilgi Eksikliği" ad1 verilen bu faktör bireylerin "Aktivitelere nasıl/nerede katılacă̆ını bilmemek" ve "Aktivitelerin yapıldı̆̆ yeri öğrenebileceğim kimsenin/yerin olmamasını" tarifleyen unsurlardan oluşur.

F8: "Arkadaş Eksikliği" adı verilen bu faktör bireylerin "Aktivitelere beraber katılacağım arkadaşlarımın zamanının olmaması", "Aktivitelere beraber katılacağım kimsenin olmaması" ve "Arkadaşlarımın bu tür etkinliklere katılmaktan hoşlanmamasını" tarifleyen unsurlardan oluşur.

F9: "Fiziksel Algı ve Săğlk" ad1 verilen bu faktör bireylerin "Fiziksel yapım bu tür etkinliklere katılmaya uygun değil", "Fiziksel görüntüm fiziksel aktivitelere katılmamı engelliyor", "Fiziksel engelim nedeniyle bu tür aktivitelere katılamıyorum", "Bu aktiviteleri yaparken kendime bir şey olacak diye kaygllaniyorum", "Bu aktiviteler strasinda denge ve koordinasyon sorunu yaşlyorum”, "Aktivitelerin yorgunluk hissi vermesi” ve "Sağlık problemlerimin varlığını" tarifleyen maddelerden oluşur.

F10: "Pahalı Bulmak" adı verilen bu faktör bireylerin "Bu tür aktiviteleri pahalı buluyorum", "Bu aktivitelerde kullanılan malzemeler bana göre pahalı" ve "Bu aktivitelere düzenli katılmanın ulaşım maliyeti bana göre pahalı" tarifleyen unsurlardan oluşur.

F11: "Ailevi Nedenler" adı verilen bu faktör bireylerin "Hasta/Yaşll/Engelli aile bireyiyle ilgilenme zorunluluğum var", "Küçük bebeğim olduğu için katılamıyorum” ve "Çocuk okuttugum için katılamıyorum" maddelerini tarifleyen unsurlardan oluşur.

Tablo 3. Madde Korelasyon Değerleri

\begin{tabular}{|c|c|c|c|c|c|c|c|c|c|c|c|}
\hline \multirow{2}{*}{ Maddeler } & \multicolumn{11}{|c|}{ Faktör Yükleri ve Korelasyon Değerleri } \\
\hline & F1 & F2 & F3 & F4 & F5 & F6 & F7 & F8 & F9 & F10 & F11 \\
\hline İlgi1 & $0.855^{* *}$ & $0.273^{* *}$ & 0.066 & -0.080 & $0.211^{* *}$ & 0.015 & 0.081 & -0.038 & 0.109 & -0.072 & -0.091 \\
\hline İlgi2 & $0.777^{* *}$ & $0.227^{* *}$ & $0.233^{* *}$ & $-0.133^{*}$ & $0.177^{* *}$ & 0.053 & -0.084 & -0.050 & $0.160^{*}$ & -0.049 & -0.113 \\
\hline İlgi3 & $0.809^{* *}$ & $0.212^{* *}$ & $0.142^{*}$ & $-0.154^{*}$ & $0.322^{* *}$ & -0.092 & $0.151^{*}$ & 0.004 & 0.002 & $0.138^{*}$ & -0.028 \\
\hline İlgi4 & $0.759^{* *}$ & $0.275^{* *}$ & 0.002 & -0.074 & 0.095 & 0.039 & -0.023 & 0.077 & -0.007 & 0.081 & -0.125 \\
\hline Tesis1 & $0.199^{* *}$ & $0.792^{* *}$ & -0.001 & $0.194^{* *}$ & $-0.210^{* *}$ & $-0231^{* *}$ & -0.085 & $0.199^{* *}$ & 0.025 & -0.039 & $-0.212^{* *}$ \\
\hline Tesis2 & $0.155^{*}$ & $0.814^{* *}$ & 0.108 & 0.039 & $-0.130^{*}$ & $-.0281^{* *}$ & 0.041 & $0.266^{* *}$ & 0.113 & -0.080 & $-0.150^{*}$ \\
\hline Tesis3 & $0.325^{* *}$ & $0.912^{* *}$ & $0.140^{*}$ & 0.011 & -0.046 & $-0.187^{* * *}$ & -0.049 & $0.236^{* *}$ & 0.115 & -0.016 & -0.111 \\
\hline Tesis4 & $0.245^{* *}$ & $0.789^{* *}$ & $0.280^{* *}$ & $-0.212^{* * *}$ & -0.114 & $-0.147^{*}$ & -0.121 & $0.219^{* * *}$ & $0.210^{* *}$ & $0.212^{* *}$ & 0.033 \\
\hline Tesis5 & $0.341^{* *}$ & $0.803^{* *}$ & $0.240^{* *}$ & -0.048 & $0.160^{*}$ & $-0.273^{* *}$ & 0.104 & $0.327^{* *}$ & $0.228^{* *}$ & -0.113 & -0.009 \\
\hline Tesis6 & $0.158^{*}$ & $0.759^{* *}$ & $0.167^{*}$ & $0.190^{* *}$ & 0.036 & -0.122 & 0.021 & $0.264^{* *}$ & 0.063 & 0.009 & -0.047 \\
\hline Tesis7 & $0.333^{* *}$ & $0.858^{* *}$ & 0.105 & 0.069 & 0.012 & $-0.160^{*}$ & -0.005 & $0.259^{* *}$ & $0.155^{*}$ & 0.060 & $-0.145^{*}$ \\
\hline Yetenek1 & 0.088 & $0.212^{* *}$ & $0.813^{* *}$ & $-0.283^{* *}$ & $0.332^{* *}$ & 0.036 & $0.203^{* *}$ & $0.362^{* *}$ & $0.349^{* *}$ & $0.179^{* *}$ & $0.301^{* *}$ \\
\hline Yetenek2 & 0.029 & 0.121 & $0.890^{* *}$ & $-0.353^{* *}$ & $0.456^{* *}$ & 0.116 & $0.143^{*}$ & $0.498^{* *}$ & $0.438^{* *}$ & $0.180^{* *}$ & $0.248^{* *}$ \\
\hline Yetenek3 & $0.150^{*}$ & 0.123 & $0.757^{* *}$ & $-0.440^{* * *}$ & $0.467^{* *}$ & 0.078 & -0.029 & $0.359^{* * *}$ & $0.526^{* *}$ & $0.235^{* *}$ & $0.282^{* *}$ \\
\hline Yetenek4 & $0.143^{*}$ & $0.151^{*}$ & $0.882^{* *}$ & $-0.273^{* *}$ & $0.399^{* *}$ & 0.084 & 0.073 & $0.422^{* *}$ & $0.526^{* *}$ & $0.205^{* *}$ & $0.344^{* *}$ \\
\hline Yetenek5 & $0.152^{*}$ & $0.156^{*}$ & $0.855^{* *}$ & $-0.446^{* *}$ & $0.351^{* *}$ & $0.170^{* *}$ & 0.061 & $0.477^{* *}$ & $0.548^{* *}$ & $0.287^{* *}$ & $0.271^{* *}$ \\
\hline
\end{tabular}




\begin{tabular}{|c|c|c|c|c|c|c|c|c|c|c|c|}
\hline Baş/aile1 & -0.126 & 0.032 & $-0.411^{* *}$ & $0.828^{* *}$ & $-0.372^{* *}$ & $-0.200^{* *}$ & -0.127 & $-0.242^{* *}$ & $-0.500^{* *}$ & $-0.356^{* *}$ & $-0.333^{* *}$ \\
\hline Baş/aile2 & $-0.172^{* *}$ & 0.007 & $-0.290^{* *}$ & $0.844^{* *}$ & $-0.273^{* *}$ & $-0.207^{* *}$ & $-0.174^{* *}$ & -0.127 & $-0.290^{* *}$ & $-0.401^{* *}$ & $-0.306^{* *}$ \\
\hline Baş/aile3 & -0.047 & 0.009 & $-0.336^{* *}$ & $0.856^{* *}$ & $-0.354^{* *}$ & $-0.196^{* *}$ & $-0.148^{*}$ & $-0.273^{* *}$ & $-0.439^{* *}$ & $-0.456^{* *}$ & $-0.271^{* *}$ \\
\hline Baş/aile4 & -0.124 & 0.078 & $-0.437^{* *}$ & $0.885^{* *}$ & $-0.409^{* *}$ & $-0.218^{* *}$ & $-0.149^{*}$ & $-0.262^{* *}$ & $-0.487^{* *}$ & $-0.489^{* *}$ & $-0.432^{* *}$ \\
\hline Baş/aile5 & -0.123 & 0.042 & $-0.360^{* *}$ & $0.879^{* *}$ & $-0.290^{* *}$ & $-0.189^{* *}$ & -0.127 & $-0.227^{* *}$ & $-0.453^{* *}$ & $-0.446^{* *}$ & $-0.342^{* *}$ \\
\hline Psiko1 & $0.248^{* *}$ & 0.062 & $0.486^{* *}$ & $-0.243^{* *}$ & $0.847^{* *}$ & 0.022 & 0.128 & $0.263^{* *}$ & $0.378^{* *}$ & -0.055 & 0.068 \\
\hline Psiko2 & $0.182^{* *}$ & -0.072 & $0.453^{* *}$ & $-0.426^{* *}$ & $0.907^{* *}$ & 0.041 & $0.239^{* *}$ & $0.206^{* *}$ & $0.269^{* *}$ & 0.009 & $0.142^{*}$ \\
\hline Psiko3 & $0.236^{* *}$ & -0.010 & $0.364^{* *}$ & $-0.278^{* *}$ & $0.819^{* *}$ & -0.015 & $0.223^{* *}$ & $0.361^{* *}$ & $0.272^{* *}$ & 0.041 & 0.026 \\
\hline Psiko4 & $0.147^{*}$ & $-0.134^{*}$ & $0.247^{* *}$ & $-0.341^{* *}$ & $0.674^{* *}$ & $0.400^{* *}$ & $0.171^{* *}$ & $0.159^{*}$ & $0.230^{* *}$ & $0.266^{* *}$ & $0.393^{* *}$ \\
\hline Zaman1 & 0.029 & $-0.149^{*}$ & 0.035 & -0.111 & 0.099 & $0.924^{* *}$ & $-0.258^{* *}$ & 0.073 & 0.007 & 0.100 & 0.074 \\
\hline Zaman2 & 0-.023 & $-0.306^{* *}$ & $0.181^{* *}$ & $-0.331^{* * *}$ & $0.163^{*}$ & $0.905^{* *}$ & $-0.139^{*}$ & 0.071 & $0.205^{* *}$ & $0.383^{* *}$ & $0.326^{* *}$ \\
\hline Bilgi1 & 0.013 & $-0.192^{* *}$ & 0.012 & $-0.154^{*}$ & $0.225^{* *}$ & -0.049 & $0.849^{* *}$ & 0.087 & -0.062 & -0.099 & -0.027 \\
\hline Bilgi2 & 0.057 & $0.159^{*}$ & $0.170^{* * *}$ & $-0.134^{*}$ & $0.176^{* *}$ & $-0.323^{* *}$ & $0.859^{* *}$ & $0.261^{* *}$ & $0.134^{*}$ & 0.057 & -0.050 \\
\hline Ark1 & 0.100 & $0.252^{* *}$ & $0.375^{* *}$ & -0.098 & $0.423^{* *}$ & -0.079 & $0.253^{* *}$ & $0.807^{* *}$ & $0.294^{* *}$ & -0.030 & -0.009 \\
\hline Ark2 & -0.055 & $0.245^{* *}$ & $0.435^{* *}$ & $-0.302^{* *}$ & $0.172^{* *}$ & $0.149^{*}$ & 0.114 & $0.894^{* *}$ & $0.447^{* *}$ & $0.166^{*}$ & $0.142^{*}$ \\
\hline Ark3 & -0.056 & $0.297^{* *}$ & $.485^{* *}$ & $-0.290^{* *}$ & $0.171^{* *}$ & $0.142^{*}$ & $0.154 *$ & $0.863^{* *}$ & $0.425^{* *}$ & $0.208^{* *}$ & $0.169^{*}$ \\
\hline Fizik1 & 0.035 & 0.100 & $0.559^{* *}$ & $-0.515^{* *}$ & $0.296^{* *}$ & $0.165^{*}$ & 0.020 & $0.363^{* *}$ & $0.779^{* *}$ & $0.375^{* *}$ & $0.246^{* *}$ \\
\hline Fizik2 & $0.204^{* *}$ & $0.216^{* *}$ & $0.406^{* *}$ & $-0.296^{* *}$ & $0.460^{* *}$ & -0.045 & $0.135^{*}$ & $0.366^{* *}$ & $0.818^{* *}$ & 0.067 & $0.167^{*}$ \\
\hline Fizik3 & 0.070 & $0.164^{*}$ & $0.525^{* *}$ & $-0.479^{* *}$ & $0.305^{* *}$ & 0.097 & 0.025 & $0.352^{* *}$ & $0.919^{* *}$ & $0.295^{* *}$ & $0.332^{* *}$ \\
\hline Fizik4 & 0.061 & 0.077 & $0.441^{* *}$ & $-0.379^{* * *}$ & $0.264^{* *}$ & $0.141^{*}$ & -0.061 & $0.466^{* *}$ & $0.836^{* *}$ & $0.286^{* *}$ & $0.257^{* *}$ \\
\hline Fizik5 & 0.043 & $0.160^{*}$ & $0.559^{* *}$ & $-0.477^{* *}$ & $0.336^{* *}$ & 0.082 & -0.014 & $0.393^{* *}$ & $0.924^{* *}$ & $0.299^{* *}$ & $0.330^{* *}$ \\
\hline Fizik6 & 0.048 & $0.136^{*}$ & $0.456^{* *}$ & $-0.508^{* *}$ & $0.281^{* *}$ & 0.112 & 0.108 & $0.421^{* *}$ & $0.863^{* *}$ & $0.298^{* *}$ & $0.279^{* *}$ \\
\hline Fizik7 & 0.031 & 0.119 & $0.472^{* *}$ & $-0.395^{* *}$ & $0.205^{* *}$ & 0.106 & 0.041 & $0.356^{* *}$ & $0.869^{* *}$ & $0.217^{* *}$ & $0.322^{* *}$ \\
\hline Pahalı1 & -0.002 & 0.038 & $0.238^{* *}$ & $-0.472^{* *}$ & 0.079 & $0.211^{* *}$ & -0.008 & 0.101 & $0.239^{* * *}$ & $0.961^{* *}$ & $0.442^{* *}$ \\
\hline Pahal12 & 0.065 & -0.012 & $0.256^{* *}$ & $-0.529^{* *}$ & 0.112 & $0.288^{* *}$ & 0.014 & $0.148^{*}$ & $0.331^{* *}$ & $0.941^{* *}$ & $0.470^{* *}$ \\
\hline Pahal13 & 0.026 & -0.007 & $0.243^{* *}$ & $-0.425^{* *}$ & 0.044 & $0.233^{* *}$ & -0.073 & 0.121 & $0.301^{* *}$ & $0.948^{* *}$ & $0.492^{* *}$ \\
\hline Aile1 & -0.019 & $-0.163^{*}$ & $0.190^{* *}$ & $-0.319^{* *}$ & $0.255^{* *}$ & $0.271^{* *}$ & -0.107 & $0.145^{*}$ & $0.252^{* *}$ & $0.286^{* *}$ & $0.740^{* *}$ \\
\hline Aile2 & -0.117 & 0.084 & $0.369^{* *}$ & $-0.288^{* *}$ & 0.035 & -0.028 & 0.036 & 0.099 & $0.276^{* *}$ & $0.355^{* *}$ & $0.761^{* *}$ \\
\hline Aile3 & -0.124 & $-0.185^{* *}$ & $0.265^{* *}$ & $-0.333^{* *}$ & $0.190^{* *}$ & $0.268^{* *}$ & -0.045 & 0.040 & $0.248^{* *}$ & $0.522^{* *}$ & $0.893^{* *}$ \\
\hline
\end{tabular}

Tablo 4. Ölçek Alt Boyut ve Maddeleri

\begin{tabular}{|c|c|c|}
\hline Boyut & $\begin{array}{l}\text { Madde } \\
\text { Numarası }\end{array}$ & Madde \\
\hline \multirow[t]{4}{*}{ İlgisizlik } & İlgi1 & Geçmişte bu tür etkinlikleri sevmedim \\
\hline & İlgi2 & Bu tür etkinliklere ilgi duymam \\
\hline & İlgi3 & Gündelik hayatın akışını bozmak istemiyorum \\
\hline & İlgi4 & Bu tür aktivitelere başlamayı sürekli ertelerim \\
\hline \multirow{7}{*}{$\begin{array}{l}\text { Tesis- } \\
\text { Hizmet- } \\
\text { Ulaşım }\end{array}$} & Tesis1 & Yakın civarımda katılabileceğim aktiviteler yok \\
\hline & Tesis2 & Aktivitelerin yapılması için tesisler yok \\
\hline & Tesis3 & Aktivitelerin yapılması için tesislerin yetersiz \\
\hline & Tesis4 & Aktivitelerin yapılabileceği tesisleri kalabalık \\
\hline & Tesis5 & Bana uygun aktivite yok \\
\hline & Tesis6 & Aktivitelerin yapıldığı yere ulaşım zaman alıyor \\
\hline & Tesis7 & Aktivitelerin yapıldığı yere ulaşım yok \\
\hline \multirow{3}{*}{$\begin{array}{l}\text { Yetenek } \\
\text { Algis1 }\end{array}$} & Yetenek1 & $\mathrm{Bu}$ aktiviteleri sürdürebilecek iradeye sahip değilim. \\
\hline & Yetenek2 & Bu aktivitelerden çabuk sıkılacağımı düşünüyorum. \\
\hline & Yetenek3 & Bu aktiviteleri hayatıma katmaya hazır değilim. \\
\hline
\end{tabular}




\begin{tabular}{|c|c|c|}
\hline & Yetenek4 & Bu aktiviteleri yapacak kadar yetenekli olduğumu düşünmüyorum. \\
\hline & Yetenek5 & $\mathrm{Bu}$ aktivitelerin gerektirdiği özellikler kişisel becerilerimle uyuşmuyor. \\
\hline \multirow{5}{*}{$\begin{array}{l}\text { Başkalarının } \\
\text { ve } \\
\text { Ailenin } \\
\text { Baskısı }\end{array}$} & Baş/aile1 & Komşularımdan çekiniyorum/utanıyorum \\
\hline & Baş/aile2 & Bu aktivitelere katılmam ailemi çevreye karşı zor durumda bırakabilir \\
\hline & Baş/aile3 & $\mathrm{Bu}$ aktivitelere katılmam ailem tarafından hoş karşılanmıyor \\
\hline & Baş/aile4 & Ailem bu aktivitelere katılmama izin vermiyor \\
\hline & Baş/aile5 & Aile bireylerinden çekiniyorum / utanıyorum \\
\hline \multirow{4}{*}{$\begin{array}{l}\text { Birey } \\
\text { Psikolojisi }\end{array}$} & Psiko1 & Bu aktiviteleri yaşıma uygun bulmuyorum \\
\hline & Psiko2 & Bu aktiviteleri benim yaşımdakiler yapmazlar \\
\hline & Psiko3 & Başkalarının katıldığı ortamlardan mutlu olmuyorum \\
\hline & Psiko4 & Boş zamanlarımı ailem için ayırmak zorunda kalıyorum \\
\hline \multirow{2}{*}{$\begin{array}{l}\text { Zaman } \\
\text { Yetersizliği }\end{array}$} & Zaman1 & İş/çalışma zamanım yoğundur \\
\hline & Zaman2 & Aile/İş sorumluluklarım nedeniyle aktivitelere zaman ayıramıyorum. \\
\hline \multirow{2}{*}{$\begin{array}{l}\text { Bilgi } \\
\text { Eksikliği }\end{array}$} & Bilgi1 & Aktivitelere nasıl//nerede katılacağını bilmiyorum \\
\hline & Bilgi2 & Aktivitelerin yapıldığ1 yeri öğrenebileceğim kimsenin/yerin olmaması \\
\hline \multirow{3}{*}{$\begin{array}{l}\text { Arkadaş } \\
\text { Eksikliği }\end{array}$} & Ark1 & Aktivitelere beraber katılacağım arkadaşlarımın zamanı yok \\
\hline & Ark2 & Aktivitelere beraber katılacağım kimse yok \\
\hline & Ark3 & Arkadaşlarımın bu tür etkinliklere katılmaktan hoşlanmıyor \\
\hline \multirow{7}{*}{$\begin{array}{l}\text { Fiziksel } \\
\text { Alg1 } \quad \text { ve } \\
\text { Sağlık }\end{array}$} & Fizik1 & Fiziksel yapım bu tür etkinliklere katılmaya uygun değil \\
\hline & Fizik2 & Fiziksel görüntüm fiziksel aktivitelere katılmamı engelliyor \\
\hline & Fizik3 & Fiziksel engelim nedeniyle bu tür aktivitelere katılamıyorum \\
\hline & Fizik4 & Bu aktiviteleri yaparken kendime bir şey olacak diye kaygılanıyorum \\
\hline & Fizik5 & Bu aktiviteler sırasında denge ve koordinasyon sorunu yaşıyorum. \\
\hline & Fizik6 & Aktivitelerin yorgunluk hissi vermesi \\
\hline & Fizik7 & Sağlık problemlerimin varlı̆̆ \\
\hline \multirow{3}{*}{$\begin{array}{l}\text { Pahalı } \\
\text { Bulmak1 }\end{array}$} & Pahalı1 & Bu tür aktiviteleri pahalı buluyorum. \\
\hline & Pahal12 & Bu aktivitelerde kullanılan malzemeler bana göre pahalı \\
\hline & Pahal13 & Bu aktivitelere düzenli katılmanın ulaşım maliyeti bana göre pahalı \\
\hline \multirow{3}{*}{$\begin{array}{l}\text { Ailevi } \\
\text { Nedenler1 }\end{array}$} & Aile1 & Hasta/Yaşl1/Engelli aile bireyiyle ilgilenme zorunluluğum var \\
\hline & Aile2 & Küçük bebeğim olduğu için katılamıyorum \\
\hline & Aile3 & Çocuk okuttuğum için katılamıyorum \\
\hline
\end{tabular}

\section{Tartışma ve Sonuç}

Bu çalışmanın amacı köyde yaşayan bireylerin hayatındaki serbest zaman kısıtlayıcılarını belirlemek için geliştirilen "Köyde Rekreasyon Engelleri Ölçeği-KREÖ” geçerlik ve güvenirlilik çalışmasını yapmaktır.

$\mathrm{Bu}$ çalışma Antalya iline bağlı Gökçam ve Karatepe köylerinde yürütülmüştür. Her iki köyden araştırmaya dâhil olmak istemiş 18 yaşın üstündeki gönüllü kadın ve erkekler örnekleme dahil edilmiştir. Karatepe köyünden 130 kişi (72 kadın 58 erkek), Gökçam’dan 101 kişi (48 kadın, 53 erkek) toplam 231 kişi anket çalışmasına dahil olmuştur.

Çalışmaya katılan katılımcıların \%51.90 (n:120)'ı kadın, \%48.10 (111)'u erkektir. Kat1lımcıların \%76.60 (n:177)'1 evli, \%23.40 (54)'1 bekârdır. Katılımcıları yaş gruplarına göre incelediğimizde çalışmaya katılan kadınların yaş ortalamaları $35.84 \pm 11.26$, erkeklerin yaş ortalamaları $36.53 \pm 12.91$ olarak bulunmuştur. Medeni duruma göre bakıldığında çalışmaya katılan evli bireylerin yaş ortalaması $39.14 \pm 10.85$, bekâr bireylerin yaş ortalamaları ise $26.46 \pm 10.70$ olarak bulunmuştur.

Araştırma verilerinin faktör yapısını ortaya çıkarmaya uygunluğunu tespit etmek amacıyla, analizlerin ilk aşamasında KMO ve Bartlett küresellik testi uygulanmıştır. KMO testi için yazın incelendiğinde 0.50 'den küçük değerin analiz için uygun olmayacağı, $0.50-0.59$ arası değerin kötü, $0.60-0.69$ aras1 değerin zayıf, $0.70-0.79$ aras1 değerin orta, $0.80-0.89$ aras1 değerin iyi, 0.90 ve üzeri değerin ise mükemmel olduğu ifade edilmektedir. Elde edilen bulgulara bakıldığında KMO örneklem yeterlilik değerinin 0.798 olduğu görülmektedir. Bu da verilerin faktör 
çıkarmak için kullanıma uygun olduğunu göstermiştir.

Anket formunun ikinci bölümünde yer alan Köydeki Rekreasyon Engelleri maddelerinin geliştirilmesinde, Alexandris ve Carrol'ın (1997) geliştirdiği ve Türkçe uyarlamasını Karaküçük ve Gürbüz'ün (2006) yaptığı Boş Zaman Engelleri Ölçeği, Karaküçük ve Gürbüz (2006) tarafından geliştirilen Boş Zaman Engelleri Ölçeği ve Öcal'ın (2012) geliştirdiği Serbest Zaman Fiziksel Aktivite Kısıtlayıcıları Ölçeği maddelerinden faydalanılmıştır. Her iki çalışmada çalışmanın amacına uygun olmadığı için her üç çalışmada yer alan maddelere ilave olarak başka maddeler de eklenerek 47 maddeden oluşan yeni bir madde havuzu oluşturulmuştur. İki madde Faktör Analizi yapıldığında düşük varyans değerleri verdiği için analizden çıkarılmış ve faktör analizi toplam 45 madde üzerinden yapılmıştır.

Karaküçük ve Gürbüz'ün (2006)'ün uyarlama çalışması olan “Boş Zaman Engelleri Ölçeği”” incelendiğinde 6 alt boyut 27 maddeden oluştuğu, örneklemini üniversitede eğitim gören öğrencilerin oluşturduğu gözlenmiştir. Yine Karaküçük ve Gürbüz (2006) tarafindan geliştirilen, örneklem olarak öğretim elemanlarının seçildiği Boş Zaman Engelleri ölçeği alt boyutlarını ve unsurlarını değerlendirdiğimizde uyarlanan boş zaman engelleri ölçeğine ilaveten maddi imkanların sorgulandığı para alt boyutunu ve sosyal ilişkilerin engel olarak tanımlanıp tanımlanmadığını belirlemek için arkadaş eksikliği ve sosyal çevre alt boyutlatının eklendiğini görmekteyiz. KREÖ'den farklı olarak Tesis ve Ulaşım iki farklı faktör olarak değerlendirilmiş, Pahalı Bulmak yerine Para ifadesi, Zaman yetersizliği yerine ise Zaman ifadesi ile tanımlanmıştır. KREÖ'de olmayan tek alt boyut Kentsel koşullar olarak ifade edilen maddelerden oluşan faktördür (Gürbüz \& Karaküçük 2006).

Öcal (2012)'ın geliştirdiği “Serbest Zaman Fiziksel Aktivite Klsıtlayıcıları (SZFA- K)" envanterinin alt boyutlarına baktığımızda ise KREÖ'den farklı olarak İrade alt boyutunu görmekteyiz. Bunun haricindeki maddeleri KREÖ ile ilişkilendirmek mümkündür. Gelir alt boyutuna eşdeğer Pahalı bulma, Sosyal çevre alt boyutuna eşdeğer Arkadaş eksikliği, Aile alt boyutuna eşdeğer Aile ve Başkalarının baskısı ve Yetenek Algısı alt boyutuna eşdeğer Fiziksel alg1 ve sağlık alt boyutu tanımlanmıştır (Öcal 2012, 50-60).

Faydalanılan rekreasyon engellerini tanımlayan ölçeğin üçü de il merkezlerinde, rekreatif etkinliğe ulaşıma daha elverişli ortamlarda ve rekreasyon, fiziksel aktivite veya sağlık bilincinde akademisyenler, idareciler veya öğrenci örneklem grupları ile geliştirilmiştir. Ancak bu çalışmada söz konusu olan örneklem grubu tanımlanan engel faktörlerinden farklı olarak çevresel ve yapısal olarak farklılık gösterdiğinden köyde yaşayan bireylerin rekreasyonel kısıtlayıcılarını tanımlamaya yönelik bir ölçek ihtiyacı ortaya çıkmıştır.

Çalışma her iki ölçekte tanımlanan engel temaları ile benzerlik göstermesinin yanı sıra köy kavramı ve yaşamının getirdiği köyün sosyolojik ve yapısal özellikler ile bağdaşan alt boyutları da tanımlamıştır. Söz konusu bulgular ve sonuçlar göz önünde bulundurulduğunda da ölçeğin Karatepe ve Gökçam örneğinde Türk popülasyonu için güvenilir bir ölçek olduğunu söylemek mümkündür.

\section{Yazar Notu}

Bu çalışma Nazlı Deniz Yılmaz’ın “Köyde Rekreasyon Engelleri Gökçam ve Karatepe Köyleri Uygulaması" isimli Akdeniz Üniversitesi, Sosyal Bilimler Enstitüsü, Rekreasyon Anabilim dalında yaptığı Yüksek Lisans tezinden üretilmiştir. XV. International Sport Science Congress, Physical Activity-Sport, 15-18 Kasım 2017, Aska Hotel, Lara/Antalya, Türkiye’de sözel sunum olarak sunulmuştur. 


\section{KAYNAKÇA}

Alexandris K. \& Carroll B. (1997). "Demographic Differences in the Perception of Constraints on Recreational Sport Participation Results from a Study in Greece”. Leisure Studies 16 (1997) 107-125.

Ardahan F. (2013). "Komşuluk, Farklılığa Hoşgörü ve Yaşam Doyumu Arasındaki İlişki, İlişkinin Güçlendirilmesinde Rekreatif Etkinliklerin Önemi”. International Journal of Human Sciences 10/1 (2013) 1078-1090.

Ardahan F., Turgut T. \& Kalkan A. K. (2016). Her Yönüyle Rekreasyon. Ankara 2016.

Balcı V. (2003). “Ankara'daki Üniversite Öğrencilerinin Boş Zaman Etkinliklerine Katılımlarının Araştırılması". Milli Ĕ̈itim Dergisi 158 (2003) 161-173.

Gümüş E. (2016). “Ünite: 7”. Türkiye'de Yerleşme Açıköğretim Fakültesi Ders Kitabı (2016) 90-92.

Gürbüz B. \& Karaküçük S. (2007). "Boş Zaman Engelleri Ölçeği-28: Ölçek Geliştirme, Geçerlik ve Güvenirlik Çalışması”. Gazi Beden Eğitimi ve Spor Bilimleri Dergisi 12 (2007) 3-10.

Kaiser H. (1974). “An Index of factor simplicity”. Psychometrika 39 (1974) 31-36.

Karaküçük S. \& Gürbüz B. (2006). "The Reliability and Validity of the Turkish Version of 'Leisure

Constraints Questionnaire”'. $9^{\text {th }}$ International Sport Sciences Congress, Congress Proceedings Book.

Koçak S. (2005). "Perceived Barriers to Exercise Among University Members". Journal of the International Council for Health Physical Education, Recreation, Spor And Dance (2005) 34-36.

Ozankaya Ö. (1987). Köyde Toplumsal Yapı Ve Siyasal Kültür (1987) 32-40.

Öcal K. (2012). “Ölçek Geliştirme: Serbest Zaman Fiziksel Aktivite Kısıtlayıcıları (SZFA-K)”. Hacettepe J. of Sport Sciences 23/2 (2012) 50-60.

Özışık Y. (1988). Kara Harp Okulu Öğretim Elemanlarının Rekreasyon Sorunları Üzerine Bir Araştırma. Yayımlanmış Yüksek Lisans Tezi. Gazi Üniversitesi, Ankara 1988.

Shinew K. J., Floyd M. F. \& Parry D. (2004). "Understanding the Relationship Between Race and Leisure Activities and Constraints: Exploringan Alternative Frame Work”. Leisure Sciences (2004) 181-199.

Zorba E., Cerit E., Gümüşdağ H. \& Evli M. (2013). "Rekreasyon Bölümlerinin Tercih Edilme Nedenleri ve Bölüm Öğrencilerinin Beklentilerinin Araştııılması”. Uluslararası Hakemli Akademik Spor Sağllk ve Tip Bilimleri Dergisi (2013) 1-14. 